\title{
Multiple C4/Slp Genes Distinguished by Expression after Transfection
}

\author{
DIANE M. ROBINS, ${ }^{1 *}$ MARIE MALISSEN,${ }^{2+}$ LEROY HOOD, ${ }^{2}$ ARTURO FERREIRA, ${ }^{3}$ DEBORAH WALTHALL,${ }^{1}$ \\ AND MARK MITCHELL ${ }^{1}$ \\ Department of Biological Sciences, Columbia University, New York, New York 10027' ; Division of Biology, California \\ Institute of Technology, Pasadena, California 911252; and Department of Pathology, New York University Medical \\ Center, New York, New York $10016^{3}$
}

Received 26 July 1985/Accepted 10 October 1985

\begin{abstract}
The $S$ region of the murine major histocompatibility complex contains two closely related genes: C4, encoding the fourth component of complement, and Slp, encoding sex-limited protein. We cloned these genes from a cosmid library of the B10.W7R strain that does not show androgen regulation of the Slp protein. Restriction site polymorphisms revealed at least four C4-like genes within the $S^{w 7}$ locus, indicating evolutionary amplification of this region. Transfection of these genes into $L$ cells resulted in expression, processing, and secretion of immunologically correct $\mathrm{C} 4$ and Slp proteins. At least two different Slp genes and one $\mathrm{C} 4$ gene were capable, after transfection, of expressing $\mathrm{C} 4$ and Slp indistinguishable from macrophage-derived protein. A third Slp gene exists within this locus whose recombinant cognate did not express in $L$ cells. Thus, the B10.W7R $S$ region includes one $\mathrm{C} 4$ gene and at least three Slp-like genes.
\end{abstract}

The $S$ region of the mouse major histocompatibility complex $(H-2)$ includes the genes for two very closely related proteins, C4 (the fourth component of complement) and Slp (sex-limited protein), that are distinct in their structure, function, and regulation (23). This system is remarkable owing to the extensive homology of the two genes and the variety of regulatory alleles existing within the $S$ locus in congenic strains of mice. Both C4 and Slp are synthesized in liver and macrophages as 200,000 -molecular-weight singlechain precursors that are similarly processed to three-chain disulfide-linked serum glycoproteins $(11,22)$. Despite extensive structural similarities of $\mathrm{C} 4$ and $\mathrm{Slp}$, including partial amino acid homologies (13), Slp has no hemolytic activity (9) and is regulated by testosterone (19). In humans, there are two $\mathrm{C} 4$ genes within the major histocompatibility complex which are both functional in the complement pathway (1), in contrast to the divergence and loss of $\mathrm{C} 4$ function for the duplicated mouse gene.

Several alleles exist for both C4 and Slp that represent regulatory as well as structural differences in the proteins. Serum concentrations of $\mathrm{C} 4$ vary 20 -fold as dictated by two major alleles, C4-high $\left(\mathrm{C}^{\mathrm{h}}\right)$ and $\mathrm{C} 4$-low $\left(\mathrm{C} 4^{\mathrm{l}}\right)(23)$. Three alleles have been described which affect regulation of Slp: (i) testosterone-regulated expression $\left(\mathrm{Slp}^{\mathrm{a}}\right)$, (ii) constitutive expression $\left(\operatorname{Slp}^{w 7}\right)$, and (iii) null expression $\left(\operatorname{Slp}^{0}\right)(12,20)$. The $\mathrm{Slp}^{\mathrm{w} 7}$ protein has been shown to have at least some structural variation from the $\mathrm{Slp}^{\mathrm{a}}$ protein, in addition to its regulatory difference $(8)$. The congenic strain $(B 10 . W 7 R)$ showing constitutive Slp expression has a $\mathrm{C}^{\mathrm{h}}$ allele that also shows structural variation as indicated by the reduced hemolytic efficiency of this C4 molecule (2).

To study the structure, regulation, and evolution of $\mathrm{C} 4$ and Slp, several groups have obtained cDNAs specifying portions of the human and mouse C4-like genes $(3,17,18$; Hemenway et al., submitted for publication). Chaplin et al.

\footnotetext{
* Corresponding author

† Present address: Centre d'Immunologie INSERM-CNRS de Marseille-Luminy, 13288 Marseille Cedex 9, France.
}

(5) have isolated a cluster of cosmid genomic clones spanning 240 kilobases $(\mathrm{kb})$ of the $S$ region of the BALB/c mouse $\left(H-2^{d}\right)$. Two C4-related cosmid clones designated C4-X and $\mathrm{C} 4-\mathrm{Y}$ that map about $50 \mathrm{~kb}$ apart were transfected into mouse L-cell fibroblasts to determine whether these clones could express correct C4 or Slp proteins (4). One of the cosmids, encompassing the $\mathrm{C} 4-\mathrm{Y}$ gene, encoded a hemolytically active $\mathrm{C} 4$ protein. The other cosmid, presumably SIp, did not express either at the RNA or at the protein level, probably owing to an incomplete $5^{\prime}$ end that lacks sequences necessary for transcription.

In this report, we describe cosmid genomic clones isolated from the B10.W7R strain that is constitutive for Slp expression. Both $\mathrm{C} 4$ and Slp proteins can be expressed from these clones in L cells, allowing us to distinguish intact C4 and Slp genes and to begin to define the boundaries of these sequences. Ultimately, we wish to compare regulatory features of different Slp alleles. This is particularly interesting for the B10.W7R strain in that this $S$ locus contains multiple $\mathrm{C} 4 / \mathrm{Slp}$ genes. Our data indicate the existence of at least three different (nonallelic) Slp-like genes, but a single C4 gene, in this congenic strain.

\section{MATERIALS AND METHODS}

Materials. Restriction and modification enzymes were purchased from New England BioLabs, Inc. (Beverly, Mass.), Bethesda Research Laboratories, Inc. (Gaithersburg, Md.), and Boehringer Mannheim Biochemicals (Indianapolis, Ind.). The construction and screening of the cosmid library and preparation of cosmid DNAs were all as described by Steinmetz et al. (24). Dulbecco modified Eagle medium was from Flow Laboratories, Inc. (McLean, Va.), and calf serum was from M.A. Bioproducts. $\left[{ }^{35}\right.$ S]methionine $(>1,000$ $\mathrm{Ci} / \mathrm{mmol}$ ) was from Amersham Corp. (Arlington Heights, IIl.). ${ }^{32}$ P-nucleotides, En ${ }^{3}$ Hance, and Gene Screen Plus were from New England Nuclear Corp. (Boston, Mass.). Protein A-Sepharose was from Pharmacia (Uppsala, Sweden). Ss and Slp antisera were the gift of V. Nussenzweig (9).

Cell culture and DNA-mediated gene transfer. Mouse $t k^{-} \mathrm{L}$ 
cells were maintained in Dulbecco modified Eagle medium supplemented with $10 \%$ calf serum. Cells were transformed with $1 \mathrm{ng}$ of ptk (the 3.6-kb BamHI fragment containing the HSV $t k$ gene inserted into pBR322), 1 to $5 \mu \mathrm{g}$ of cosmid DNA, and $15 \mu \mathrm{g}$ of carrier Ltk $^{-}$DNA per $10^{6}$ cells, as described by Wigler et al. (25). Transformants were selected and maintained in Dulbecco modified Eagle medium with $10 \%$ calf serum, $15 \mu \mathrm{g}$ of hypoxanthine per $\mathrm{ml}, 1 \mu \mathrm{g}$ of aminopterin per $\mathrm{ml}$, and $5 \mu \mathrm{g}$ of thymidine per $\mathrm{ml}$ (HAT medium).

Southern and Northern blotting. High-molecular-weight DNA and total cellular RNA were prepared as previously described $(6,21,25)$. DNA was digested to completion with $2 \mathrm{U}$ of restriction enzyme per $\mu \mathrm{g}$ of DNA, fractionated by agarose gel electrophoresis, and transferred to nitrocellulose. RNA was denatured by heating in formaldehydeformamide, fractionated through agarose gels containing $6.0 \%$ formaldehyde (15), and transferred to Gene Screen Plus. Filters were hybridized to ${ }^{32} \mathrm{P}$ probes labeled by nick translation of $\mathrm{C} 4$ and Slp cDNAs isolated in this laboratory (Hemenway et al., in preparation). In some experiments, C4and Slp-specific single-stranded oligonucleotide probes were synthesized on an Applied Biosystems model 380A DNA synthesizer and ${ }^{32} \mathrm{P}$ end labeled with $\mathrm{T} 4$ polynucleotide kinase. Hybridization and washing conditions were standard.

Nucleic acid probes. cDNA probes used in this study derive from C4 and Slp cDNA clones of both $H-2^{d}$ and $H-2^{n-7}$ mice. Sequence comparisons reported $(17,18)$ and unpublished data from this laboratory indicate up to $95 \%$ homology for most regions of $\mathrm{C} 4$ and Slp, and thus long cDNA probes hybridize equally well to both sequences. The cDNA probe used in Fig. 1 was a 1.2-kb C4 fragment from the 3' end of the mRNA which simplifies the blot pattern otherwise obtained for these large genes. This cDNA fragment encompassed the coding region for the last 160 amino acids of the $\alpha$ peptide chain and all but the last 30 amino acids of the $\gamma$ chain. cDNA probes used in other experiments (Fig. 3 and 6) encompassed about $3.6 \mathrm{~kb}$ of the $\mathrm{C} 4 \mathrm{mRNA}$, extending from the poly(A)-addition site. C4- and Slp-specific probes were synthesized to regions where the $\mathrm{C} 4$ and Slp sequences diverge significantly. One region occurs immediately $3^{\prime}$ to the $\mathrm{COOH}$ terminal of the $\mathrm{C} 4 \mathrm{a}$ peptide, as also noted by Nonaka et al. (17). Single-stranded oligonucleotides (23 bases) synthesized to this region of the $\mathrm{C} 4$ and SIp sequences differ in 12 of the 23 nucleotides. A second region of marked sequence divergence, as also noted by Ogata and Sepich (18), occurs shortly before the cleavage signal between the $\alpha$ and $\gamma$ peptide chains where $C 4$ and Slp differ in 7 of 25 bases. Oligonucleotide probes synthesized to this region also hybridized specifically to C4 or Slp.

Biosynthetic labeling and immunoprecipitation of $\mathrm{C} 4$ and Slp. Cells $\left(2 \times 10^{6}\right)$ were plated in 60 -mm culture dishes and incubated overnight in HAT medium plus $10 \%$ calf serum. Cells were starved for $20 \mathrm{~min}$ in methionine-free Dulbecco modified Eagle medium with $10 \%$ dialyzed fetal calf serum and then radiolabeled for 2 to $4 \mathrm{~h}$ in $1 \mathrm{ml}$ of fresh medium with $100 \mu \mathrm{Ci}$ of $\left[{ }^{35} \mathrm{~S}\right]$ methionine. After incubation, the medium was harvested, and cells washed thoroughly and lysed as previously described (10). Peritoneal macrophages from two to four mice per dish were treated essentially identically. Samples of lysates and media were incubated at $0^{\circ} \mathrm{C}$ for $1 \mathrm{~h}$ with an excess of anti-Ss or anti-Slp serum. Immune complexes were precipitated with protein A-Sepharose, washed, solubilized, reduced, and analyzed by sodium dodecyl sulfate-polyacrylamide gel electrophoresis (14). Fixed gels were treated with $\mathrm{En}^{3} \mathrm{Hance}$, dried, and fluorographed. Radioimmunoassays from dishes of confluent cells were performed as described in detail previously (7).

\section{RESULTS}

Multiple C4/Slp genes occur in the $H-2^{w 7} S$ locus. The $\mathrm{C} 4 / \mathrm{Slp}$ genes of several congenic mouse strains were initially examined to correlate differences in gene structure with different modes of C4/SIp expression. C4 and Slp cDNA sequences are about $95 \%$ homologous for regions examined so far and thus cross-hybridize extensively (see above), yet expression of the genes is markedly dissimilar. The B10.W7R strain $\left(H-2^{w \cdot 7}\right.$ haplotype) shows high expression of $\mathrm{C} 4\left(\mathrm{C}^{\mathrm{h}}{ }^{\mathrm{h}}\right)$ and constitutive expression of Slp (Slp $\left.{ }^{\mathrm{w} 7}\right) ; \mathrm{B} 10 . \mathrm{D} 2$ mice $\left(H-2^{d}\right)$ show high expression of $\mathrm{C} 4$ and testosteroneregulated expression of SIp $\left(\operatorname{Slp}^{\mathrm{a}}\right)(23)$. Neither B10.BR $\left(H-2^{k}\right)$ nor B6/KH $\left(H-2^{b}\right)$ strains express Slp $\left(\mathrm{Slp}^{0}\right)$; the former strain exhibits low expression of $\mathrm{C} 4\left(\mathrm{C}^{\mathrm{l}}\right)$, while the latter is $C 4^{\mathrm{h}}(23)$. Restriction site polymorphisms have been found that distinguish each haplotype.

A different blot pattern was obtained for each haplotype when a 1.2-kb C4 probe from the $3^{\prime}$ portion of the cDNA was hybridized to HindIII-digested genomic DNA (Fig. 1). Molecular maps of the $S$ locus from an $H-2^{d}$ mouse (5) indicate that the $\operatorname{Slp}^{\mathrm{a}}$ gene is largely encompassed within the $23-\mathrm{kb}$ HindIII fragment (18). The $\mathrm{C} 4$ gene has internal HindIII sites resulting in hybridization of the $3^{\prime} \mathrm{cDNA}$ probe to 4.8 - and 6-kb C4 fragments. The C4 4.8-kb HindIII fragment is the only band present in all four haplotypes. In the $H-2^{k}$ haplotype, sequence polymorphisms may correlate with low C4 expression. Neither $\boldsymbol{H}-2^{b}$ nor $\boldsymbol{H}-2^{k}$ mice express Slp; the 23-kb HindIII fragment characteristic of Slp ${ }^{\mathrm{a}}$ is present in the $H-2^{k}$ haplotype but not in the $H-2^{b}$, indicating possible allelic variants of the $\operatorname{SIp}^{0}$ phenotype.

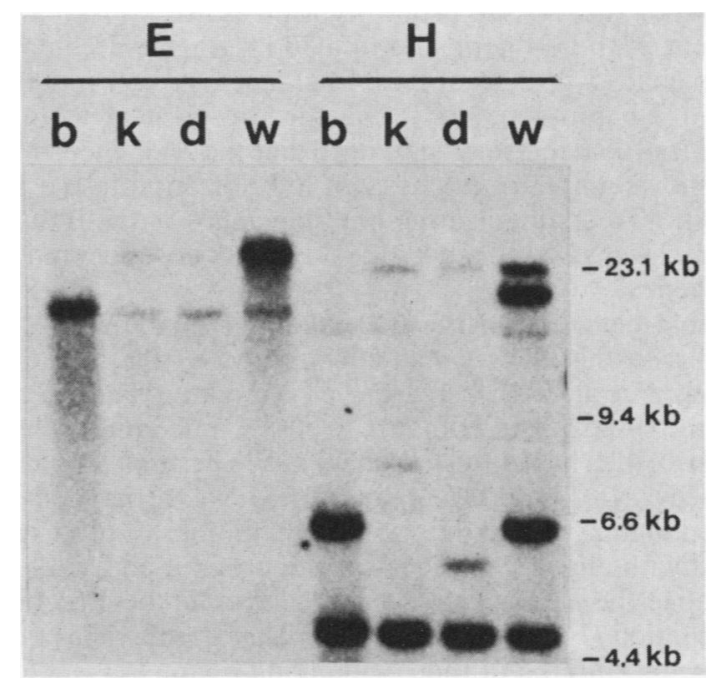

FIG. 1. Hybridization of mouse liver DNAs with C4 cDNA. DNA (15 $\mu \mathrm{g}$ per lane) was digested with EcoRI (E) or HindIII (H), electrophoresed on a $0.8 \%$ agarose gel, and Southern blotted as described in the text. and the filter was hybridized to a 1.2-kb C4 cDNA probe from the $3^{\prime}$ portion of the coding sequence. This probe encompasses the coding region for the last 160 amino acids of the $\alpha$ peptide chain and all but the last 30 amino acids of the $\gamma$ chain. Haplotypes indicated above each lane are those of the following strains: B6.KH (b); B10.BR (k). B10.D2 (d); B10.W7R (w7; indicated as lane $w$ ). Molecular weight markers were from a HindIII digest of $\lambda$ DNA. 
TABLE 1. Expression of B10.W7R cosmids in transfected $\mathrm{L}$ cells

\begin{tabular}{cclcc}
\hline Cell line & Cosmid & Oligo $^{a}$ & $\begin{array}{c}5.7-k b \\
\text { mRNA }^{b}\end{array}$ & $\begin{array}{c}\text { SIp RIA } \\
\text { (cpm) }\end{array}$ \\
\hline 1 & 4.4 & C4 & - & ND $^{d}$ \\
2 & 8.1 & C4 & - & ND \\
3 & 9.1 & Slp & + & 87 \\
4 & 11.1 & Slp & - & 0 \\
5 & 13.4 & Slp & - & ND \\
6 & 15.3 & Slp & + & 1,332 \\
7 & 16.2 & C4 & + & 25 \\
8 & 27.2 & Slp & + & 5,280 \\
9 & 35.6 & C4 & + & ND \\
10 & 38.3 & Slp & + & 1,800 \\
11 & 43.7 & C4 & + & 99 \\
12 & 49.3 & C4 & + & 14 \\
13 & 59.1 & Slp & + & ND \\
14 & 60.2 & Slp & + & 314 \\
15 & 12.5 & C4 & + & ND \\
\hline
\end{tabular}

${ }^{a}$ Specific oligonucleotide hybridizing to cosmid clone DNA. The 23-mers made to the $\mathrm{C} 4$ and Slp cDNA sequences near the $\mathrm{COOH}$ terminus of the $\mathrm{C} 4 \mathrm{a}$ peptide are only $50 \%$ homologous to each other in sequence, unlike other portions of the cDNAs which show 95\% homology (17), and are thus C4- or Slp-specific.

${ }^{b}$ Expression of 5.7-kb mRNA shown to cross-hybridize with C4/Slp cDNA on Northern blots.

' Counts per minute above background in RIA of cell media. Ltk ${ }^{-}$cells (background) showed $473 \mathrm{cpm}$ in this assay; B10.W7R sera diluted $1 / 2,000$ showed $8,345 \mathrm{cpm}$ above background.

${ }^{d}$ ND, Not done.

The $H-2^{w 7}$ hybridization pattern is the most complex, showing a greater number and intensity of hybridizing fragments. As also noted by Levi-Strauss et al. (16), the testosterone-independent expression of Slp in the $w 7$ haplotype seems to correlate with multiple C4/Slp genes, whereas two C4-like genes are present in other haplotypes. This can be seen most clearly in the EcoRI digestion of Fig. 1. In the $d$ haplotype, the cDNA probe hybridizes to a 17-kb EcoRI fragment of the $\mathrm{C} 4$ gene and to a $30-\mathrm{kb}$ fragment containing the Slp gene $(5,18)$. This $30-\mathrm{kb}$ fragment is greatly intensified in the $w 7$ haplotype, indicating the presence of additional genes. It is also interesting to note that the $H-2^{b}$ mouse $\left(C 4^{\mathrm{h}}\right.$, $\mathrm{Slp}^{0}$ ) shows a greater intensity of hybridization to the $17-\mathrm{kb}$ fragment. To distinguish the multiple genes of the B10.W7R $S$ locus, we isolated and characterized cosmid clones of these genes.

Cosmid clones from the B10.W7R $S$ region. A B10.W7R genomic cosmid library was constructed by the methods of Steinmetz et al. (24), using the pTL5 vector, and screened with a 300-base-pair human C4 cDNA encoding a central portion of the human $\mathrm{C} 4 \alpha$ chain (3). The first four clones obtained $(2.1,41.1,41.2$, and 41.3$)$ were mapped with restriction enzymes to determine possibilities of overlap and probed with oligonucleotides specific to $C 4 \alpha$ and $\gamma$ subunits to localize the coding regions and determine the direction of transcription (Fig. 2). These cosmids showed similar coding regions but differed in their $3^{\prime}$ flanking regions, as indicated perhaps best by differences in SmaI and BamHI sites. Thus, these clones seem to represent three different genes, as seen by the restriction site differences.

The cosmid library was rescreened with probes that encompassed more coding information (the Sma E and G fragments [Fig. 2]), and 47 strongly hybridizing colonies were picked. An additional polymorphism within these clones was detected by hybridizing SmaI-digested DNAs with the Sma-G probe after Southern transfer. For most of the cosmids (including those of Fig. 2), a 0.9-kb SmaI 


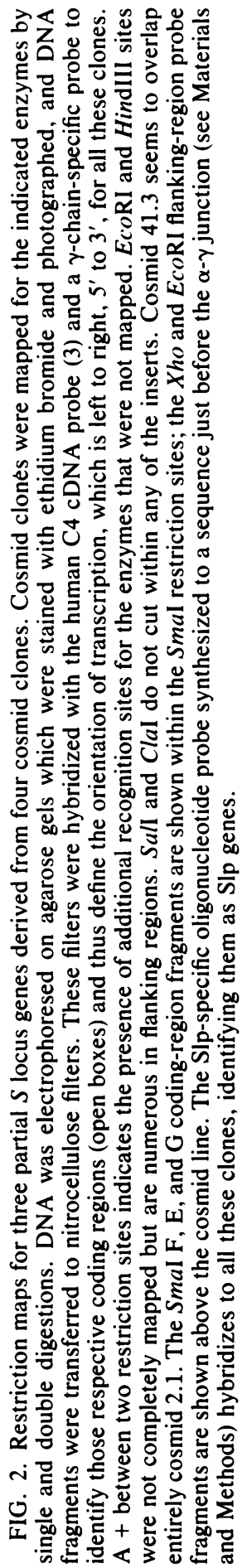

fragment hybridized to the Sma-G probe, whereas other cosmids showed a $3.7-\mathrm{kb}$ fragment hybridizing instead. Cosmids with the $3.7-\mathrm{kb}$ fragment represent a gene in addition to the first three characterized. Thus, restriction site polymorphisms within the cosmid clones indicate that there are at least four different C4-like genes within the B10.W7R $S$ region.

Transfection and expression of C4-like genes. To identify which cosmids encode intact $\mathrm{C} 4$-like genes and whether these are capable of synthesizing immunospecific C4 or Slp protein, we introduced several cosmids into mouse $\mathrm{L}$ cells. Since data from this laboratory and others (5) indicate that the $\mathrm{C} 4$ gene is about $20 \mathrm{~kb}$ in length, we chose for transfer those cosmids which hybridized to coding-region probes, but not to 3' flanking probes (Fig. 2). Therefore, these clones could contain no more than $20 \mathrm{~kb} 3^{\prime}$ to the gene and were likely to have sufficient regulatory and coding information to specify transcription of C4 or Slp. Of the 51 cosmids, 15 had this hybridization pattern (Table 1). These 15 cosmids were further identified by hybridization to oligonucleotide probes specific for $\mathrm{C} 4$ or Slp that were derived from cDNA sequence differences at the $\mathrm{COOH}$ terminus of the $\mathrm{C} 4 \mathrm{a}$ peptide (see above). Of these 15 cosmids, 7 hybridized to the $\mathrm{C} 4$ probe, and 8 hybridized to the Slp oligomer.

These 15 cosmid DNAs were individually cotransfected into $\mathrm{Ltk}^{-}$cells by using ptk as the selectable marker (25). For each of the 15 cotransfections, 9 independent $\mathrm{TK}^{+}$ colonies were picked and grown up as stable cell clones. In Southern blots of total DNA from $\mathrm{TK}^{+}$cell clones, donor sequences were identified by hybridization with C4 and SIp cDNA probes (data not shown). Transferred genes capable

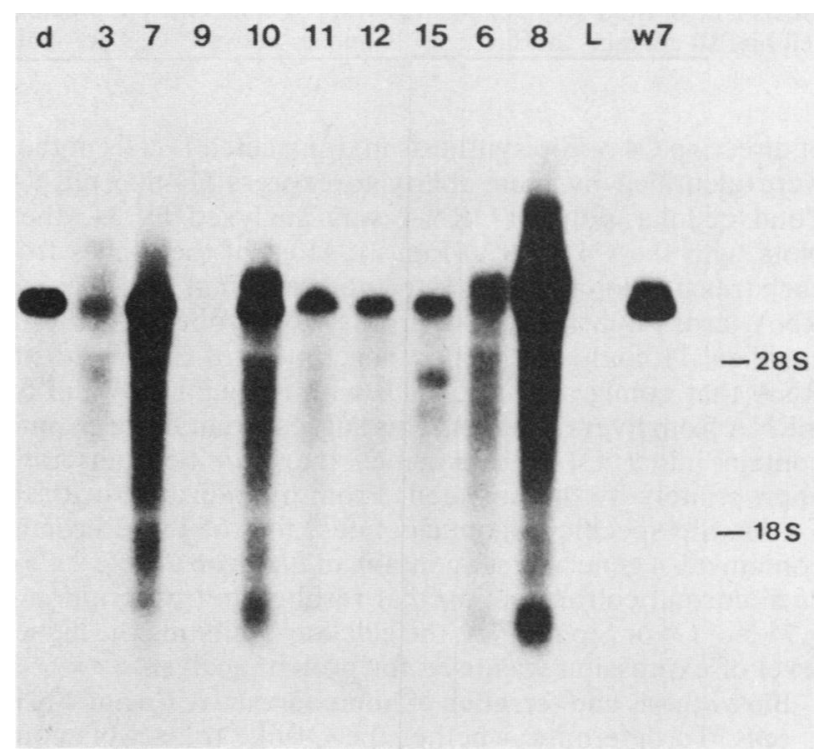

FIG. 3. Expression of C4 and Slp mRNA in L-cell cotransformants. Total cellular poly $(\mathrm{A})^{+} \mathrm{RNA}$ was isolated from $\mathrm{Ltk}^{+}$cell lines. as described in Materials and Methods. This RNA was run on Northern blots as described in the text and hybridized to nicktranslated C4 cDNA. The lanes are numbered in accord with the transfected cell line number (see Table 1). The first and last lanes contain $0.5 \mu \mathrm{g}$ of female liver poly $(\mathrm{A})^{+}$RNA from B10.D2 (lane d) or B10.W7R (lane w7) mice, respectively. The other lanes, derived from L-cell RNAs, all contain $5 \mu \mathrm{g}$ of $\operatorname{poly}(\mathrm{A})^{+}$RNA. except lanes 12. 6. and 8, which each contain $1 \mu \mathrm{g}$ of $\operatorname{poly}(\mathrm{A})^{+}$RNA. The $L$ lane contains $10 \mu \mathrm{g}$ of poly $(\mathrm{A})^{+}$RNA from Ltk cells. Autoradiography was for $16 \mathrm{~h}$. 


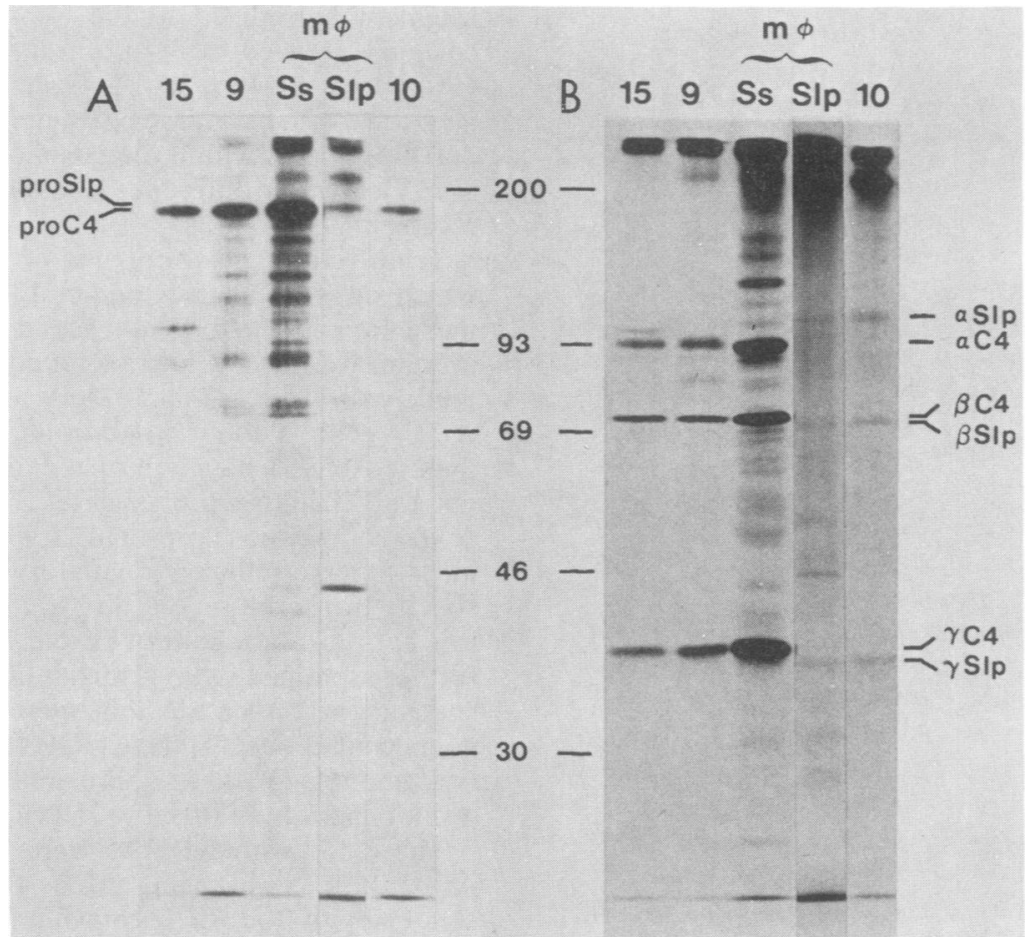

FIG. 4. Biosynthesis and secretion of $\left[{ }^{35} \mathrm{~S}\right]$ methionine-labeled $\mathrm{C} 4$ and Slp. Cells were cultured and labeled and media and cell lysate samples were immunoprecipitated as described in Materials and Methods. For this gel, all samples were incubated with rabbit anti-Ss serum, except the macrophage $(\mathrm{m} \phi)$ Slp sample which was incubated with mouse anti-Slp serum. (A) Immunoprecipitates of cell lysates; (B) protein immunoprecipitated from extracellular media. All samples were electrophoresed on the same $10 \%$ sodium dodecyl sulfate-polyacrylamide gel, but panel $\mathrm{A}$ is from a 1-day exposure and panel $\mathrm{B}$ is from a 1-week exposure. The macrophage lane of panel B required a 6-week exposure, possibly owing to the thermolability of processed Slp and the weaker affinity of the anti-Slp antibody. The Slp-specific bands can be seen in the Ss lane of the 1-week exposure owing to more efficient precipitation with the less-specific antiserum. Cell lines 15 and 9 contain C4 genes; cell line 10 contains an Slp gene. Numbers between gels are molecular weight $\left(\times 10^{3}\right)$ markers.

of directing C4 or Slp synthesis in transfected L cells initially were identified by their ability to express C4-like mRNA. Total cellular poly $(\mathrm{A})^{+}$RNA was analyzed by Northern blots with the C4 cDNA (Fig. 3). Most of the clones from each transfection that contained donor cosmid DNA showed RNA cross-hybridizing with the C4 probe. Of the 15 cosmids, 11 could direct the transcription of C4-hybridizing RNA that comigrated at $5.7 \mathrm{~kb}$ with authentic C4 and Slp mRNA from liver (Table 1). This suggests that these cosmids contain intact $\mathrm{C} 4$ or Slp genes that can be transcribed appropriately by the host cell. From hybridization with the C4- or Slp-specific oligonucleotides, five of these cosmids contain a $\mathrm{C} 4$ gene and six contain an Slp gene (Table 1). For each cosmid cotransfection that resulted in transcription of $5.7 \mathrm{~kb}$ of $\mathrm{C} 4$ or Slp mRNA, the cell line exhibiting the highest level of expression was used for protein analysis.

Biosynthesis and secretion of immunoreactive C4 and Slp by $\mathbf{L}$ cells. To determine whether the C4-like transcripts could be translated into pro-C4 and pro-Slp molecules capable of being processed and secreted by $L$ cells, biosynthetically radiolabeled cellular and secreted proteins were characterized. Cell lysates and extracellular media were reacted with rabbit anti-Ss sera, which recognizes both $\mathrm{C} 4$ and Slp, or mouse anti-Slp sera that is specific for Slp. Cells containing a 5.7-kb C4 or Slp mRNA also produced immunoprecipitable pro-proteins of approximately 200,000 molecular weight, as in peritoneal macrophages (Fig. 4A), whereas $\mathrm{L}$ cells themselves did not (data not shown). Pro-Slp was detectably larger than pro-C4.
Transfected $\mathrm{L}$ cells are capable of processing the precursors and secreting them into the media where they are found correctly cleaved into $\alpha, \beta$, and $\gamma$ chains of sizes similar to those found in macrophages (22). Cell lines 15 and 9 both contained $\mathrm{C} 4$ genes and secreted proteins with chain sizes of 95,000, 74,000, and 34,000 molecular weight. Processed Slp is readily distinguished from $\mathrm{C} 4$ owing to significant size differences in the peptide chains. The $\alpha$ chain of Slp is 105,000 molecular weight, which is larger than the $\mathrm{C} 4 \alpha$ chain. The Slp $\beta$ and $\gamma$ chains are somewhat smaller than their $\mathrm{C} 4$ counterparts, having molecular weights of 72,000 and 32,000, respectively. Because the Slp molecule is thermolabile, its accumulation in medium of $L$ cells is noticeably less than for $\mathrm{C} 4$. To further verify the identity and authenticity of these proteins, we performed a radioimmunoassay (RIA) for Slp (7) on media from nine cotransfected L-cell lines, each containing a different cosmid DNA, as well as on $\mathrm{Ltk}^{-}$control cells (Table 1). Two different monoclonal antibodies directed at separate epitopes on the Slp molecule both detected significant Slp levels in the media of four cell lines containing $\mathrm{Slp}^{\mathrm{w7}}$ genes, but not in media from $\mathrm{Ltk}^{-}$ cells or any of the cell lines with foreign $\mathrm{C} 4$ genes. Cell line 3 is a low expressor of Slp, as seen by its mRNA level (Fig. 3 ) and a faint pro-Slp band on protein gels (data not shown). Therefore, the RIA activities of cell lines 3 and 11 (C4 expressing) are considered not significantly above background in this assay.

Distinct $\mathrm{Slp}^{\mathrm{w7}}$ genes are capable of expressing polypeptides. Although multiple $\mathrm{C} 4 / \mathrm{Slp}$ genes exist in the B10.W7R 


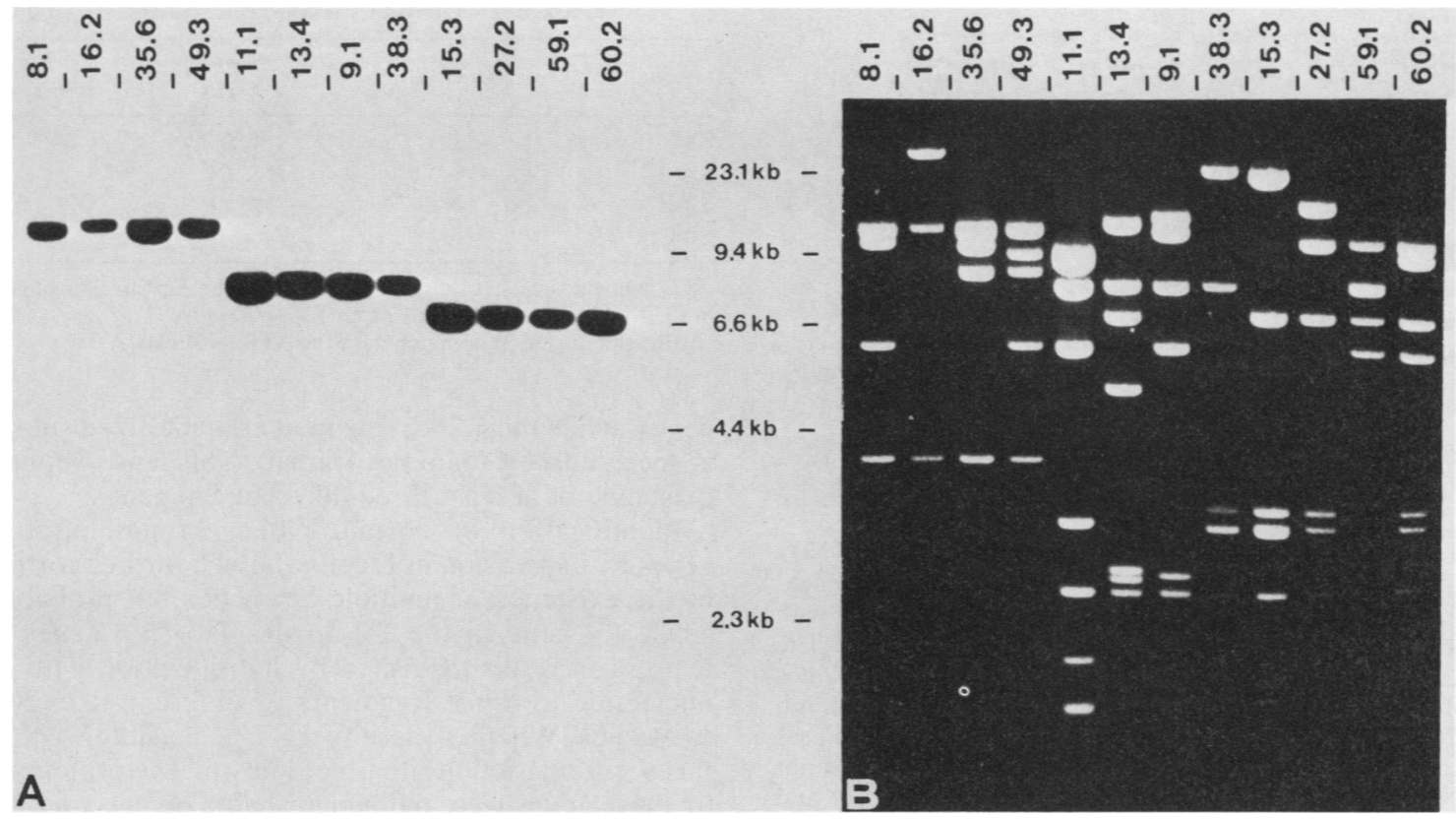

FIG. 5. Hybridization of Smal-digested cosmid clone DNAs. A 300-ng sample of B10.W7R cosmid clone DNAs, indicated above each lane, was digested with $S \mathrm{maI}$, electrophoresed on a $0.8 \%$ agarose gel, and transferred to nitrocellulose. (A) Hybridization of the filter to both the C4- and Slp-specific oligonucleotides, from the $\mathrm{COOH}$ terminus of the C4a peptide, which were ${ }^{32} \mathrm{P}$ end labeled to $2 \times 10^{8} \mathrm{cpm} / \mu \mathrm{g}$. Hybridization of identical filters with either the $\mathrm{C} 4$ or the Slp probe shows the C4 probe hybridizing only to the 11-kb band in the first four lanes and the Slp probe hybridizing only to the 8- and 6.5-kb bands of the eight right lanes. Thus, the first four cosmids on the left contain C4 genes; the other eight cosmids shown contain Slp genes. (B) Photograph of the gel stained with ethidium bromide before transfer. Numbers between gels show molecular weight markers.

mouse, protein heterogeneity has not been noted. Additional $\mathrm{C} 4$ or Slp genes could be substantially similar with respect to their protein product or could represent pseudogenes or only partially duplicated genes. Of particular interest is the possibility of similar genes that express but are differentially regulated. To assess the number and expression of different C4 and Slp genes in the $w 7 S$ locus, we examined structural gene differences of the cosmid clones in conjunction with the transfection data. Since most of the restriction site differences between the cosmid clones relate to the extent of their inserts, we more rapidly scanned for heterogeneity by probing Southern blots of cosmid DNAs.

Initial characterization of multiple Slp genes derives from restriction site differences and hybridization studies with the C4- and Slp-specific oligonucleotide probes. Figure 5 shows a SmaI digestion difference among the Slp clones. Of the eight SIp cosmid clones transfected into L cells, four showed hybridization with a 6.5-kb SmaI fragment and four hybridized with an 8-kb SmaI fragment (Fig. 5A). All four of the cosmid clones that contained the 6.5-kb SmaI fragment were capable of expressing Slp after transfection into $\mathrm{L}$ cells (Table 1). Of those clones containing the 8-kb SmaI fragment, two expressed Slp and two did not show a 5.7-kb mRNA. These eight cosmids are independent isolates, as seen by their unique SmaI digestion patterns on the gel before transfer (Fig. 5B). The difference in the size of the hybridizing fragment in the two groups of clones is not due to differential extents of recombinant insert, because cosmid vector does not hybridize to this band (data not shown). The cosmids that express $\mathrm{C} 4$ after transfection into $\mathrm{L}$ cells, and one of the nonexpressing C4 cosmids, had an 11-kb SmaI fragment that hybridized to the $\mathrm{C} 4$ oligonucleotide (Fig. 5A). The remaining nonexpressing $\mathrm{C} 4$ cosmid showed no hybrid- ization with this probe and was presumably missing much of the $5^{\prime}$ portion of the gene (data not shown). Thus, the SmaI restriction pattern can distinguish two different and expressible cloned Slp genes, but fails to detect a heterogeneity within $\mathrm{C} 4$ genes. The heterogeneity of SmaI sites within $\mathrm{SIp}^{\mathrm{w} 7}$ genes cannot be shown directly in the genome because these sites are methylated in vivo.

A further heterogeneity within $\operatorname{Slp}^{\text {w7 }}$ genes was seen after digestion with the enzyme HindIII and can be substantiated by comparison with a genomic digest of DNA from the congenic B10.W7R strain. HindIII digests of cosmid DNAs from five C4-containing cosmid clones (Fig. 6, on the left of lane w7) were probed with a $3.6-\mathrm{kb}$ C4 cDNA. All the C4 clones had a 15-kb HindIII fragment as seen in the $w 7$ genomic digest (lane 6 ). All the C4-expressing clones also had the 4.8-kb HindIII fragment, whereas cosmid 8.1 did not and thus may not express owing to the absence of requisite 3 ' information. Of the eight Slp clones (on the right of lane w7), only cosmids 11.1 and 13.4 did not express in L cells. Five of the cosmids that did express showed a 19-kb HindIII fragment that also hybridized intensely in the genomic digest. At least two different Slp genes contain this fragment in the genome, since cosmid 38.3 had the $8-\mathrm{kb} S \mathrm{maI}$ fragment, whereas the other four were characterized by the 6.5-kb SmaI fragment (Fig. 5). Three additional HindIII fragments that occurred in the genomic digest (of 23,11 , and $6.6 \mathrm{~kb}$ ) were found in cosmid 11.1 , which does not express in L cells. Whether cosmids 13.4 and 9.1 represent another Slp gene(s) or appear different owing to the limits of the recombinant insert has not yet been determined. A summary of the distinct $S^{w \cdot 7}$ genes is presented in Table 2 . This analysis reveals two distinguishable Slp genes that are capable of expression in $\mathrm{L}$ cells and a third Slp gene that may lack 
Mol. Cell. Biol.

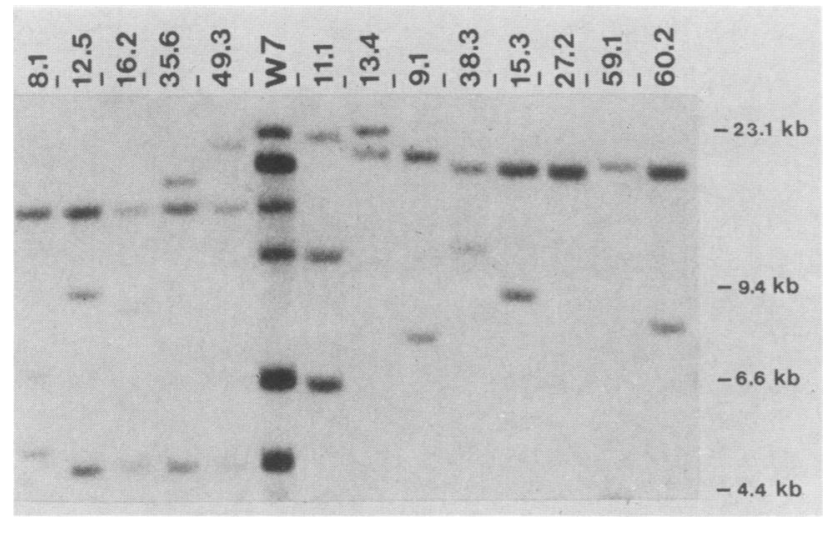

FIG. 6. Hybridization of HindIII-digested cosmid clone DNAs and B10.W7R liver DNA. Each cosmid DNA (25 pg) (indicated above each lane) and salmon DNA $(15 \mu \mathrm{g})$ were digested with HindIII, as well as $15 \mu \mathrm{g}$ of B10.W7R liver DNA (lane w7). The cosmid DNAs are arranged in the same order as in Fig. 5 (C4 clones to the left of the $w 7$ lane, Slp clones to the right), with the addition of cosmid 12.5 which expresses $\mathrm{C} 4$ after transfection. C4 cosmid 8.1 does not express in L cells; Slp cosmids 11.1 and 13.4 also do not express. DNAs were electrophoresed on a $0.5 \%$ agarose gel and transferred to nitrocellulose, and the filter was hybridized to a $3.6-\mathrm{kb}$ C4 cDNA extending from the $3^{\prime}$ terminus of the mRNA. Numbers on the right show molecular weight.

requisite regulatory information in cosmid 11.1 or may represent an Slp pseudogene in the $S^{117}$ locus.

\section{DISCUSSION}

The variety of regulatory alleles for $\mathrm{C} 4$ and Slp that exist in congenic mouse strains make the $S$ locus an attractive system for studies of gene expression and evolution in addition to complement structure and function. Previous studies $(4,5)$ have described $S$-region genes from an $H-2^{d}$ mouse $\left(C 4^{h}\right.$, Slp $\left.p^{a}\right)$ and have shown that this $C 4$ allele leads to production of hemolytically active $\mathrm{C} 4$ after transfection into mouse L-cell fibroblasts. In this report, we present evidence that the $S$ locus of the B10.W7R mouse $\left(\mathrm{C}^{\mathrm{h}}\right.$. Slp ${ }^{\mathrm{w} 7}$ : constitutive rather than sex-limited expression of Slp) contains multiple C4/Slp genes and that both proteins can be expressed and processed after gene transfer of isolated cosmid clones. Introduction of these genes into heterologous cells may be the most straightforward means to determine exactly how many different and (potentially) expressible C4 and SIp genes are present in this mouse strain. since the large size and extensive homology of these genes would otherwise require inordinate molecular characterization. Further, transfection into hormonally responsive host cells may determine if multiple Slp genes are under similar or different regulation.

That the $S^{117}$ locus contains multiple C4/Slp genes is indicated by additional and more intensely hybridizing fragments relative to other haplotypes on genomic Southern blots (Fig. 1). Quantitative blot hybridizations of LeviStrauss et al. (16) show single C4 and Slp genes in most mouse strains, except those with testosterone-independent expression of SIp in which multiple C4/Slp genes are found. In support of this notion, at least four different $S^{117}$ genes were indicated by restriction site polymorphisms in isolated cosmid clones. Identification of the cosmid inserts as $\mathrm{C} 4$ or Slp by expression in L cells or by hybridization to the C4- or Slp-specific oligomers revealed that the $0.9-\mathrm{kb}$ Smal fragment found in the three cosmids of Fig. 2 is present in SIp
TABLE 2. Distinct C4/Slp genes in the $S^{w 7}$ locus

\begin{tabular}{lccc}
\hline Gene & Smal $^{u}(\mathrm{~kb})$ & $\begin{array}{c}\text { HindIII } \\
(\mathrm{kb})\end{array}$ & $\begin{array}{c}\text { Representative } \\
\text { cosmid clone }\end{array}$ \\
\hline $\mathrm{C4}^{\mathrm{u} 7}$ & 11 & 4.8 .15 & 35.6 \\
$\mathrm{SlpA}^{\mathrm{w7}}$ & 6.5 & 19 & 27.2 \\
$\mathrm{SlpB}^{\mathrm{u} 7}$ & 8 & 19 & 38.3 \\
$\mathrm{SlpC}^{\mathrm{w} 7}$ & 8 & 23.11 .6 .6 & 11.1 \\
\hline
\end{tabular}

"Fragment size hybridizing with the C4- or Slp-specific oligonucleotide probe to the $\mathrm{COOH}$ terminus of the $\mathrm{C} 4 \mathrm{a}$ peptide.

"Fragment size hybridizing with the 3.6-kb C4 cDNA.

genes, while the $3.7-\mathrm{kb}$ fragment characterized subsequently is specific to $\mathrm{C} 4$ (data not shown). This lends support to the existence of at least three different Slp genes.

Identification of cosmid clones containing full-length genes by expression in $\mathrm{L}$ cells allowed further corroboration of the existence of multiple Slp genes but probably only a single $\mathrm{C} 4$ gene in the $S^{n 7}$ locus. Two Slp genes that can express were distinguished by hybridization with an oligonucleotide to Smal fragments of different sizes within the two genes. Whether these two Slp genes differ by more than this $S$ maI restriction site is not known. The proteins encoded by these genes were indistinguishable on gels and were both recognizable by using three different Slp-specific antibodies. Thus, the genes are unlikely to differ significantly at least in regions encoding SIp-specific epitopes and cleavage sites.

The two Slp genes that can express in $L$ cells share in common a 19-kb HindIII fragment. A third Slp gene shows a different HindIII restriction pattern that correlates with additional bands in the $w 7$ genome. The cosmid containing this gene does not express in L cells and so may be lacking necessary transcription signals. Alternatively, it may represent a pseudogene in the B10.W7R mouse. While the 23-kb HindIII fragment of cosmid 11.1 is similar in size to the Slp-specific fragment in the $H-2^{d}$ mouse (Fig. 1), the other fragments of these two Slp genes do not coincide.

The hybridization pattern for the HindIII digest of $H-2^{\text {w.7 }}$ DNA can be accounted for by a minimum of four different C4/Slp genes, each specific to the $w 7$ haplotype (Table 2). We have no evidence as yet for more than one $\mathrm{C} 4$ gene in the "1.7 genome. Both $H-2^{d}$ and $H-2^{w 7} \mathrm{C} 4$ genes are $\mathrm{C} 4^{\mathrm{h}}$ alleles, yet differ in their HindIII restriction sites. This may relate to structural differences in the two $\mathrm{C} 4$ proteins resulting in the lower hemolytic efficiency of $\mathrm{C} 4$ from $\mathrm{H}-2^{117}$ mice (2). The distinct Slp $^{\text {w7 }}$ genes may now be distinguished as in Table 2 as SIpA. SlpB, and SIpC. Further molecular mapping and overlapping of these cosmid clones should elucidate the physical arrangement of these genes and be informative for mechanisms of gene duplication. It is striking that constitutive expression of Slp correlates not just with multiple C4/SIp genes (16) but, at least for the B10.W7R strain, with apparent amplification of just the Slp gene. It will be interesting to determine whether the products of multiple and recent (16) gene duplications still all reside within the $S$ locus, and whether any partial gene copies or hybrid C4/SIp genes are present.

That both C4 and Slp can be expressed, processed, and secreted by mouse L-cell fibroblasts indicates that the enzymatic machinery necessary for cleavage and modification of these proteins may be constitutively expressed in a variety of cells. Thus, expression of individual genes by transfection may allow protein differences to be detected and ascribed to different $S^{\prime \prime 7}$ genes. Transfections into hormonally responsive cell lines should also be useful in localizing DNA sequences underlying the differential regulation of SIp ${ }^{a}$ and 
$\operatorname{Slp}^{w 7}$ alleles. Furthermore, it is conceivable that distinct $\operatorname{Slp}^{w 7}$ genes are themselves regulated differently. In vivo, an $\mathrm{Slp}^{\mathrm{w} 7}$ gene that was in fact regulated by testosterone might not be detected above high constitutive expression of Slp in both sexes. For genes as large and homologous as $\mathrm{C} 4$ and Slp, transfection studies provide a functional assay for localizing DNA sequence differences of structural or regulatory significance or both more rapidly and definitively than structural gene comparisons alone.

\section{ACKNOWLEDGMENTS}

We thank Helen Doyle for technical assistance, Ruth Montague for art work, and Becky Mitchell for preparing the manuscript. Moses Chao, Laurel Eckhardt, Larry Chasin, and Richard Axel provided helpful discussions. We gratefully acknowledge Victor Nussenzweig for giving us the B10.W7R mouse strain and antisera to initiate this work.

Support for this investigation was from Public Health Services grant GM31546 (D.M.R.) from the National Institutes of Health. RIA characterization was supported by Public Health Service grant AI13224 (A.F.) from the National Institutes of Health.

\section{LITERATURE CITED}

1. Alper, C. A. 1981. Complement and the MHC, p. 173-220. In M. E. Dorf, The role of the major histocompatibility complex in immunology. Garland STPM Press, New York.

2. Atkinson, J. P., K. McGinnis, L. Brown, J. Peterein, and D. C. Shreffler. 1980. A murine C4 molecule with reduced hemolytic efficiency. J. Exp. Med. 151:492-497.

3. Carroll, M. C., and R. R. Porter. 1983. Cloning of a human complement component $\mathrm{C} 4$ gene. Proc. Natl. Acad. Sci. USA 80:264-267.

4. Chaplin, D. D., R. Sackstein, D. Perlmutter, J. H. Weis, T. A. Kruse, J. Coligan, H. R. Colten, and J. G. Seidman. 1984. Expression of hemolytically active murine fourth component of complement in transfected L cells. Cell 37:569-576.

5. Chaplin, D. D., D. G. Woods, A. S. Whitehead, G. Goldberger, H. R. Colten, and J. G. Seidman. 1983. Molecular map of the murine S region. Proc. Natl. Acad. Sci. USA 80:6947-6951.

6. Chirgwin, J. M., A. E. Przbyla, R. J. MacDonald, and W. J. Rutter. 1979. Isolation of biologically active RNA from sources rich in RNase. Biochemistry 18:5294-5299.

7. Ferreira, A., D. Eichinger, and V. Nussenzweig. 1982. The murine sex-limited protein $(\mathrm{Slp})$ : reassessment of its sexlimitation. J. Immunol. 129:1506-1508.

8. Ferreira, A., J. Michaelson, and V. Nussenzeig. 1980. H-2 controlled polymorphism of the $\gamma$ chain of Slp. Immunogenetics 11:491-497.

9. Ferreira, A., V. Nussenzweig, and I. Gigli. 1978. Structural and functional differences between the H-2 controlled Ss and Slp proteins. J. Exp. Med. 148:1186-1197.

10. Goldberger, G., G. N. Abraham, J. Williams, and H. R. Colten. 1980. $\mathrm{NH}_{2}$-terminal sequence analysis of pro-C4. the precursor of the fourth component of guinea pig complement. J. Biol. Chem. 255:7071-7074.
11. Hall, R. E., and H. R. Colten. 1977. Cell-free synthesis of the fourth component of guinea pig complement: identification of a precursor of serum C4 (pro-C4). Proc. Natl. Acad. Sci. USA 74:1707-1710.

12. Hansen, T. H., and D. C. Shreffler. 1976. Characterization of a constitutive variant of the murine serum protein allotype, Slp. J. Immunol. 117:1507-1513.

13. Karp, D. R., K. L. Parker, D. C. Shreffler, C. Slaughter, and J. D. Capra. 1982. Amino acid sequence homologies and glycosylation differences between the fourth component of murine complement and sex-limited protein. Proc. Natl. Acad. Sci. USA 79:6347-6349.

14. Laemmli, U. K. 1970. Cleavage of structural proteins during the assembly of the head of bacteriophage T4. Nature (London) 227:680-685.

15. Lehrach, H., D. Diamond, J. M. Wozney, and H. Boedtker. 1977. RNA molecular weight determinations by gel electrophoresis under denaturing conditions, a critical reexamination. Biochemistry 16:4743-4747.

16. Levi-Strauss, M., M. Tosi, M. Steinmetz, J. Klein, and T. Meo. 1985. Multiple duplications of complement C4 gene correlate with $\mathrm{H}$-2-controlled testosterone-independent expression of its sex-limited isoform, C4-Slp. Proc. Natl. Acad. Sci. USA 82: 1746-1750.

17. Nonaka, M., M. Takahashi, S. Natsuume-Sakai, M. Nonaka, S. Tanaka, A. Shimizu, and T. Honjo. 1984. Isolation of cDNA clones specifying the fourth component of mouse complement and its isotype, sex-limited protein. Proc. Natl. Acad. Sci. USA 81:6822-6826.

18. Ogata, R. T., and D. S. Sepich. 1984. Genes for murine fourth complement component (C4) and sex-limited protein (Slp) identified by hybridization to C4- and Slp-specific cDNA. Proc. Natl. Acad. Sci. USA 81:4908-4911.

19. Passmore, H. C., and D. C. Shreffler. 1970. A sex-limited serum protein variant in the mouse: inheritance and association with the $\mathrm{H}-2$ region. Biochem. Genet. 4:351-365.

20. Passmore, H. C., and D. C. Shreffler. 1971. A sex-limited serum protein variant in the mouse: hormonal control of phenotypic expression. Biochem. Genet. 5:201-209.

21. Robins, D. M., I. Paek, P. Seeburg, and R. Axel. 1982. Regulated expression of human growth hormone genes in mouse cells. Cell 29:623-631.

22. Roos, M. H., J. P. Atkinson, and D. C. Shreffler. 1978. Molecular characterization of the Ss and SIp (C4) proteins of the mouse $\mathrm{H}-2$ complex: subunit composition, chain size polymorphism, and an intracellular (Pro-Ss) precursor. J. Immunol. 121:1106-1115.

23. Shreffler, D. C. 1976. The S region of the mouse major histocompatibility complex (H-2): genetic variation and functional role in the complement system. Transplant. Rev. 32:140-167.

24. Steinmetz, M., A. Winota, K. Minard, and L. Hood. 1982. Clusters of genes encoding mouse transplantation antigens. Cell 28:489-498.

25. Wigler, M., R. Sweet, G. K. Sim, B. Wold, A. Pellicer, E. Lacy, T. Maniatis, S. Silverstein, and R. Axel. 1979. Transformation of mammalian cells with genes from procaryotes and eucaryotes. Cell 16:777-785. 